Case Report

\title{
CYSTIC FIBROSIS IN AN ADULT - A RARE CASE - DIAGNOSED AND CONFIRMED BY A NEW, NOVEL, INDIGENOUS TECHNIQUE
}

\author{
Raghava Sharma ${ }^{1}$, Raghu Raj', Sukanya Shetty ${ }^{3}$ \\ ${ }^{1}$ Professor, Dept. of M edicine, ${ }^{2}$ Assistant professor, Dept. of Radiology \\ ${ }^{3}$ Professor and head, Dept. of Bio Chemistry, K.S. Hegde M edical Academy, M angalore - 575018. \\ Correspondence \\ Raghava Sharma, \\ Professor, Dept. of M edicine, K.S. Hegde M edical Academy, M angalore - 575018. \\ Mobile : +9194487 70919 E-mail : rrsharma1967@yahoo.com
}

\begin{abstract}
: technique of Sweat chloride estimation. estimation.

\section{Introduction :}

Cystic fibrosis (CF) is an important autosomal recessive disease and data from western Countries indicate an incidence rate of 1 in 2500 live births. But no such data is available for the Indian context.
\end{abstract}

Cystic fibrosis (CF) is an important autosomal recessive disorder caused due to genetic mutation thus affecting the chloride channel . It involves multiple systems particularly lungs, respiratory tract and gastro intestinal tract. It is mainly considered as a disease of pediatric population. However it is being reported from adult population, more frequently from the western countries due to better survival.

CF is reported very rarely from India and report of adult CF is much more rarer. Conformation of CF is by HRCT (High resolution computerized tomography), gene mutation analysis and sweat chloride estimation. However sweat chloride test presently being employed (called pilocarpine iontophoresis) is costly, very complicated and is not available even in most advanced centers in India.

Our case highlights the need for a high index of suspicion for suspecting CF in adults with chronic respiratory symptoms, and the need for a cost effective, easily available, reproducible, standardized test technique for sweat chloride estimation.

Here with we present a case of CF (cystic fibrosis) in an adult male of 23 years whose diagnosis was confirmed by a new novel indigenous

Keywords : Cystic fibrosis, Adult Cystic fibrosis, Sweat chloride estimation, New novel indigenous technique of Sweat chloride

Mutations affecting the CFTR (cystic fibrosis trans membrane conductance regulator) gene located on the long arm of chromosome 7 leads to the development of CF , as it affects the salt and water movement across cell membranes.

CF manifests in the early childhood and is characterized by chronic pulmonary Access this article online Quick Response Code same. It also highlights the need, necessity, importance infection, bronchectasis, pancreatic insufficiency and elevated sweat chloride level. Presently due to various therapeutic a d v a n c e s a n d improvement in survival rate, CF do exist in adult population, though it is rare.

Presently the techniques for confirming the diagnosis of CF by gene mutation analysis and sweat chloride estimation by pilocarpine iontophoresis are not cost effective and also not easily available.

The present case highlights the presence of $\mathrm{CF}$ in adults and the necessity for a high index of suspision to detect the and relevance of confirming the diagnosis by a cost effective, easily available, reproducible and standardized sweat chloride estimation technique. A NEW NOVEL

Indigenous Technique (fully Explained Under The Discussion Part Of The Article), Developed At Ks Hegde M edical Acadamy, M angalore, A Constituent Unit Of Nitte University Fulfills The Same.

\section{Case Profile :}

A 23 year old male presented to KS Hegde medical academy hospital in the month of August 2012, for persistant cough with expectoration, breathlessness of 22 years duration 
with exacerbation of the same along with fever and headache of 1 day duration.

The complete descriptions of his symptoms all along the course were as follows:

Breathlessness: Being present throughout the day, even at rest, with out diurnal variation, associated with wheeze.

Cough: Used to be present throughout the day, more in the early morning, increasing on leying on sides.

Expectoration : Used to get minimal expectoration till the age of 18 years, but later on copious, two cups per day, thick viscid greenish yellow, exaggerated on each exacerbations, non foul smelling, more in early morning and leying on to sides, occasionally blood tinged with minor haemoptysis at the age of $18 \& 22$ years.

Fever: Used to be high grade with chills, along with exacerbation of breathlessness, cough \& expectoration.

Head ache: Used to be severe frontal head ache along with fever \& exacerbation of breathlessness, cough \& expectoration.

The frequency of exacerbation of symptoms were once in 2 yearstill he was 8 years old;

and once in every year till he was 18 years old, but manageable by OPD care. But now since the age of 18 years onwards, the exacerbation of symptoms had become 3-4 times per year and necessitated admission and treatment asin patient only.

No other noteworthy history was forthcoming and none of the other family members including first degree relatives suffered from similar complaints.

Physical examination: His general physical examination revealed height of 1.52 metres, weight of $40 \mathrm{kgs}$ and BM I of $17.3 \mathrm{~kg} / \mathrm{sq} \mathrm{mts}$; stable vitals; afebrile ; grade 2 clubbing without cyanosis ; no lymphadenopathy \& no edema. He had breathlessness at rest with a respiratory rate of 25 per minute with accessory muscles of respiration being active. Oxygen saturation was $90 \%$. Respiratory system examination revealed chest with bilaterally symmetrical indrawing at lower coastal margins ( FIG -6 ) with a chest expansion of 2-3 cms. Percussion note was normal bilaterally and coarse crepitations were heard bilaterally all over lung fields, more so in the bilateral mammary and infra axillary areas. Ocassional ronchi were also heard. Other systems particularly cardiovascular system, per abdomen, and central nervous system were conspicuously normal.

He was thoroughly evaluated (Table $1 \&$ Table 2 ) and confirmed to have " cystic fibrosis " based on the " new novel indigenous technique for the estimation of sweat chloride content".

As the diagnosis of cystic fibrosis (a rare disorder in an adult) was confirmed, he was provided with " counseling for himself and his family members " and was managed conservatively with relevant antibiotics, bronchodilators, mucolytics, oxygen inhalation \& other supportive measures.

He was discharged on being symptomatically better after 10 days of treatment in the hospital.

\section{Discussion :}

Cystic Fibrosis is a genetic disorder which is autosomal recessive in inheritance and due to mutations in the CFTR (cystic fibrosis transmembrane conductance regulator) gene. M ore than 1200 mutations in the CFTR gene has been recognized. The most common CFTR mutation in northern European and American populations is Delta F 508.[Ref 1]A frequency of $19 \%$ - $44 \%$ of Delta F 508 mutation has been reported in very few small studies from India.[Ref 2]. Cystic fibrosis has been rarely reported from India and data on various gene mutations is not available from India.

Due to recessive inheritance and smaller nuclear families, Cystic fibrosis cases are commonly seen in a single member of the family. Our case also reiterates the same.

The genetic defect causes an increased sodium chloride content in sweat and increased potential difference across the respiratory epithelium. This leads to increased viscosity of secretions in the lung and other organs causing ciliary dysfunction and chronic bronchial infection. Recurrent exacerbations of bronchial infection lead to bronchial wall 
TABLE - 1 (Profile of investigations during course of illness )

\begin{tabular}{|c|c|c|}
\hline $\begin{array}{l}\text { Investigations on multiple } \\
\text { occasions. }\end{array}$ & $\begin{array}{l}\text { Patients values with } \\
\text { normal range. }\end{array}$ & $\begin{array}{l}\text { Impression } \\
\text { Normal. }\end{array}$ \\
\hline$* \mathrm{Hb}$ & $13.9-15.8 \mathrm{~g} / \mathrm{dl}(11-15)$ & High TC suggestive of infection. \\
\hline * TC - Total count. & $\begin{array}{l}\text { 10900-18100cells/cu mm } \\
(4000-10000)\end{array}$ & $\begin{array}{l}\text { High neutrophil count suggestive } \\
\text { of infection. }\end{array}$ \\
\hline * DC - Differential count \% & $\begin{array}{l}N: 85-88 \\
L: 11-13 \\
E: 2-5\end{array}$ & Normal. \\
\hline * ESR & $4-25 \mathrm{~mm} / \mathrm{hr}(<15)$ & Normal. \\
\hline * Platelet count & $\begin{array}{l}294000-360000 \\
(1.5-4 \text { lakhs })\end{array}$ & Normal. \\
\hline * MPFT & Negative. & Impaired glucose metabolism. \\
\hline * Urine & $\begin{array}{l}\text { Albumin present. } \\
\text { Sugar -Greenish yellow. }\end{array}$ & \\
\hline * RBS - Random blood Sugar & $121-138 \mathrm{mg} / \mathrm{dl}(70-140)$ & Impaired glucose metabolism. \\
\hline * FBS - Fasting blood Sugar & $160-179 \mathrm{mg} / \mathrm{dl}(100-110)$ & Impaired glucose metabolism. \\
\hline * Blood urea. & $11-21 \mathrm{mg} / \mathrm{dl}(13-45)$ & Normal. \\
\hline * S Creatinine & $0.6-0.7 \mathrm{mg} / \mathrm{dl}(<1.4)$ & Normal. \\
\hline * Serum Sodium & 132.9-138.2 mmol/It (135 - 148 ) & Normal. \\
\hline * Serum Potassium & 4- $4.4 \mathrm{mmol} / \mathrm{lt}(3.5-5$ ) & Normal. \\
\hline * Serum Chloride & $87.7-101 \mathrm{mmol} / \mathrm{lt}(98-101$ ) & Decreased. \\
\hline * Total Protein & $8-8.6 \mathrm{gm} / \mathrm{dl}(6.6-8.3)$ & Normal. \\
\hline * Albumin & $4.1-4.3 \mathrm{gm} / \mathrm{dl}(3.5-5$ ) & Normal. \\
\hline * Globulin & $3.9-4.3 \mathrm{gm} / \mathrm{dl}(2.3-3.5)$ & Normal. \\
\hline * A / G ratio & $1(1-1.5)$ & Normal. \\
\hline * Total bilirubin & $0.2 \mathrm{mg} / \mathrm{dl}(<1.0)$ & Normal. \\
\hline * Direct bilirubin & $0.1 \mathrm{mg} / \mathrm{dl}(<0.25)$ & Normal. \\
\hline * Indirect bilirubin & $0.1 \mathrm{mg} / \mathrm{dl}(<0.75)$ & Normal. \\
\hline * SGOT & $20-24 \mathrm{U} / \mathrm{It}(<40)$ & Normal. \\
\hline * SGPT & $10 \mathrm{U} / \mathrm{It}(<40)$ & Normal. \\
\hline * Alk phosphatase & $110-128 \mathrm{U} / \mathrm{It}(60-170)$ & Normal. \\
\hline * Hiv , HbsAg , Hcv & Negative. & Normal. \\
\hline * Sputum for AFB & Negative & Normal. \\
\hline $\begin{array}{l}\text { * Sputum for culture } \\
\text { sensitivity. }\end{array}$ & $\begin{array}{l}\text { - Positive for gm +ve cocci in pairs and chains. } \\
\text { - Few gm +ve and gm - ve bacilli. } \\
\text { - Coagulase - ve staphylococcus. } \\
\text { - Pseudomonas aerogenosa. }\end{array}$ & $\begin{array}{l}\text { Staphylococcal and } \\
\text { Pseudomonas infections } \\
\text { Conspicuous on multiple } \\
\text { Occasions. }\end{array}$ \\
\hline
\end{tabular}

damage and bronchectasis of both lungs. Genetic defect also leads to alterations in gut epithelium, pancreatic and liver alterations causing diabetes, malabsorption, and hepatic cirrhosis.[Ref 3]. Thus cystic fibrosis is charectarised by chronic pulmonary infection, bronchectasis, pancreatic insufficiency, altered glucose metabolism, diabetes mellitus and elevated sweat chloride level.[Ref 4]. Our present case also had chronic pulmonary infection, bronchectasis, and altered glucose metabolism. The other features reported to be associated with cystic fibrosis include cataract, deficient growth, obstructive azoospermia (in males).Our present case had deficient growth but without other associated features.

Lung function is usually normal at birth and recurrent respiratory infection with chronic cough and wheeze misdiagnosed as bronchial asthma leads to bronchectasis , which usually develops at a young age. In majority, respiratory infections are usually due to Staphylococcus aureus and pseudomonas. The same was also noted in our present case. Repeated lung infection, inflammation and scarring invariably lead to respiratory failure and death. 
TABLE - 2 (Profile of special investigations during course of illness )

\begin{tabular}{|c|c|c|}
\hline Investigations. & Observation and details. & Impression. \\
\hline * ECG & Normal & Cardiac involvement not evident. \\
\hline * Echo cardiogram. & $\begin{array}{l}\text { LV function - Normal } \\
\text { LVEF - } 60 \% \\
\text { Valves - Normal. } \\
\text { RA, RV - M ildly dilated }\end{array}$ & M ild pulmonary hypertension. \\
\hline * Chest $\mathrm{X}$ ray PA view. (FIG - 5) & $\begin{array}{l}\text { Ring like and cystic opacities in } \\
\text { RM Z, RLZ, } \\
\text { LLZ, with low set and } \\
\text { flattened domes of diaphragms. }\end{array}$ & $\begin{array}{l}\text { Suggestive of Bronchectasis } \\
\text { With emphysematous changes } \\
\text { and normal Cardiac size } \& \text { silhousette. }\end{array}$ \\
\hline$* \mathrm{X}$ ray PNS waters view & $\begin{array}{l}\text { Bilateral frontal and maxillary sinuses clear with } \\
\text { mild deviation of nasal septum towards left. }\end{array}$ & Normal PNS radiograph. \\
\hline $\begin{array}{l}* \text { HR CT Chest } \\
(\text { FIGS }-1,2,3,4)\end{array}$ & $\begin{array}{l}\text { - Extensive cystic \& varicose Bronchectatic } \\
\text { changes involving both lungs, predominantly } \\
\text { central and Rt > Lt with complete collapse of } \\
\text { RML. ( FIG - } 1,2 \text { ) } \\
\text { - Areas of M osaic perfusion in both lungs \& } \\
\text { Branching nodular tree in bud opacities in } \\
\text { periphery \& both lower lobes with no } \\
\text { Intra / inter lobular septal thickening. (FIG - 3,4) }\end{array}$ & Diagnostic of Cystic Fibrosis. \\
\hline * Sweat for chloride estimation. & $\begin{array}{l}\text { New Novel Indigenous technique employed. } \\
\text { (Explained fully under discussion). } \\
\text { Sweat chloride from } 3 \text { samples from } 3 \text { different } \\
\text { sites were } 111.6 \mathrm{mmol} / \mathrm{Lt} \\
101.6 \mathrm{mmol} / \mathrm{Lt} \text { and } 109.6 \mathrm{mmol} / \mathrm{Lt} \text {. }\end{array}$ & $\begin{array}{l}\text { High sweat chloride } \\
\text { CONFIRM ATORY OF CYSTIC FIBROSIS. } \\
\text { [ Normal sweat chloride is } \\
10-35 \mathrm{mmol} / \mathrm{Lt} \text { and } \\
\text { always }<60 \mathrm{mmol} / \mathrm{Lt} \text {. ] }\end{array}$ \\
\hline
\end{tabular}

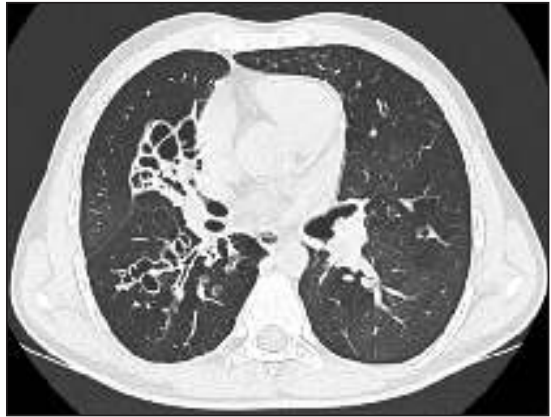

FIG - 1: HRCT Chest -Varicose and cystic bronchectasis in both lungs, Right > Left.

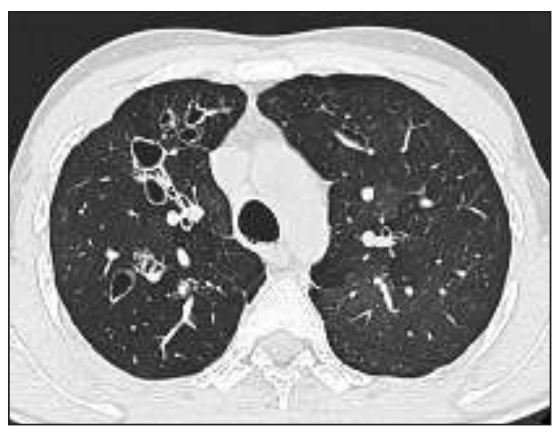

FIG - 4: HRCT Chest- Geographic areas of hypo \& hyper attenuated lung fields with prominent vessels suggestive of Mosaic perfusion.

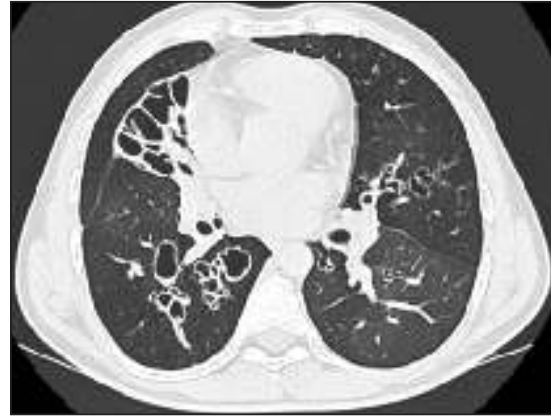

FIG - 2: HRCT Chest- Cystic bronchectasis in both lungs, peri bronchial thickening \& collapse of Rt middle lobe.

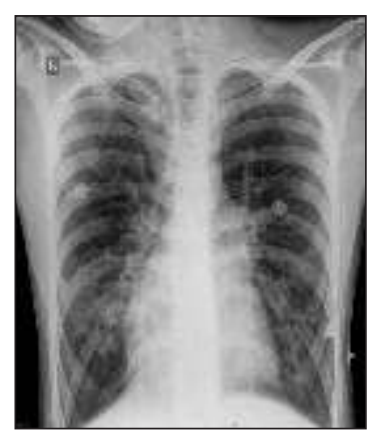

FIG - 5: X ray Chest- Bilateral bronchectasis with emphysematous changes.

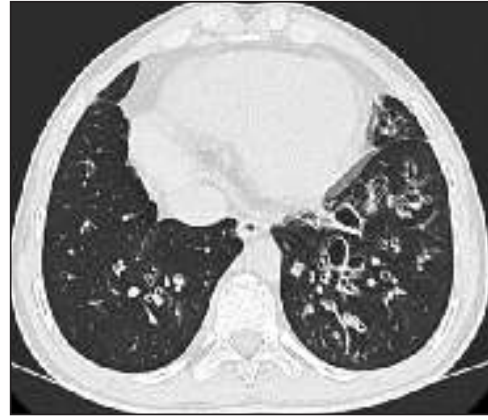

FIG - 3: HRCT Chest- Air fluid level in dilated bronchi of LLB \& tree in bud opacities along the periphery.

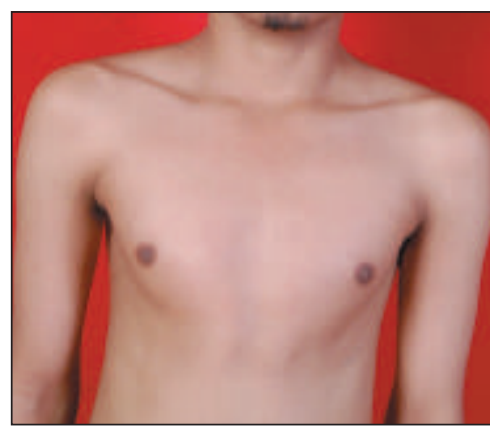

FIG - 6: Chest appearance of the case with bilateral lower pectoral indrawing. 
However due to available better antibiotics and medical advances patients do survive to adulthood.

Diagnosing cystic fibrosis in adults is a challenge for physician as it needs a high index of suspision due to its rarity and chances of misdiagnosis.

Confirming the diagnosis of cystic fibrosis is by demonstrating a high sweat chloride content ( $>60 \mathrm{mmol} / \mathrm{lt}$ but usually $>100 \mathrm{mmol} / \mathrm{It}$ ) and / or identifying two CF mutations. But it is difficult in Indian context due to non availability of these tests.[ Ref 5 ]. Presently sweat chloride is measured by "Pilocarpine iontophoresis" which involves a complicated procedure requiring weak electrical stimulus, two electrodes containing pilocarpine gel discs and special sweat collector. The disadvantages of this being very costly and not easily available even in most modern centresin India.

So it reiterated that, for India there is an absolute need for a cheap but standardized, easily reproducible technique for sweat chloride estimation for early confirming cystic fibrosis which helps in early psychosocial rehabilitation for both the patient and their family and also to achieve better outcomes. Our new, novel, indigenous technique fulfills all these requirements.

NEW NOVEL INDIGENOUS TECHNIQUE FOR SWEAT CHLORIDE ESTIM ATION

\section{Methodology:}

This technique was evolved at KS Hegde medical academy, M angalore, a constituent unit of Nitte university, along with the active collaboration of department of Biochemistry.

Instrumentsused:

G 3 sterile cotton swabs

G 25 micro litre pipette.

$\mathrm{G}$ Sterile water for injection from a reputed manufacturer.

G C8C centrifuge \& R8Claboratory centrifuge - REM I.

G 902 Automatic analyzer (Hitachi ).

\section{Methodology employed:}

G Neck, chest, back and both arms of patient were cleaned and was made to sit in front of warmer.

G 3 samples of sweat of 25 microlitre each from above 3 different sites was (pipetted and) absorbed on to 3 cotton swabs with no touch technique.

G All 3 swabs were immediately transported to biochemistry laboratory of KS Hegde medical academy hospital in a sterile container with no touch technique precaution.

G The swabs were transferred in to centrifuge test tubes with no touch technique and 500 microlitre $(0.5 \mathrm{ml})$ of sterile water for injection were added to each. The test tubes were centrifuged for 5 minutes at $3000 \mathrm{rpm}$. The fluid in the test tubes with the extracted sweat were analyzed for "chloride" using automatic analyzer. The sterile water for injection used, was also subjected to chloride estimation.

G The chloride values thus obtained from sweat samples from different sites were corrected for the dilution component. ( dilution due to addition of sterile water for injection ). A correction factor of 20 was employed in view of 20 times dilution of sweat.

\section{Advantages of this new technique:}

$\mathrm{G}$ Easily available.

G Cheap.

G Standardized (as standard validated instruments were used).

G Easily reproducible with accuracy.

\section{Conclusions.}

G Cystic fibrosis though a paediatric disorder can still be present in adults due to improved medical care and better survival.

G Physicians should have a high index of suspicion to detect Adult Cystic fibrosis particularly in those who have chronic dyspnoea, sinusitis \& low body weight.

$G$ Tests to identify CF gene mutation ( to confirm diagnosis of Cystic fibrosis ) is not readily available, not cost effective and also not practicable.

G Sweat chloride estimation is practicable for confirming the diagnosis of cystic fibrosis. But the presently available technique ( pilocarpine iontophoresis) is 
cumbersome, costly, and rarely available in India.

G Our new indigenous technique of sweat chloride estimation is cheap, standardized and easily reproducible. It offers a new ray of hope as it can over come the lacuna of non available sweat testing facilities even in most modern centres in India. It also heralds the confirmed diagnosis of cystic fibrosis ( a rare condition ) at the earliest ,thus paving way for better management and better outcomes. However our new technique needs to be employed on wider number of patients and validated for wider acceptance.

\section{References}

1. Wilmot RW. Making the diagnosis of cystic fibrosis. J pediatrics 1998;132: 563-5.

2. Ashavaid TF, Dherai AJ, Kondkar AA, et al. M olecular diagnosis of cystic fibrosis in Indian patients-a preliminary report. J Assoc physicians India 2003;51: 345-8.

3. William B Guggino. Cystic fibrosis and the salt controversy. Cell 1999;96: 607-10.

4. ON Bhakoo, Rajkumar, BNS Walia. Mucoviscidosis of the lung. Indian journal of pediatrics 1968; 35: 183-185.

5. Stern RC. The diagnosis of cystic fibrosis. New England journal of Medicine 1997;336: 487-491. 